\title{
PENGEMBANGAN KERANGKA KONSEPTUAL MODEL RANTAI PASOK HALAL PADA KOMODITAS DAGING AYAM DI KABUPATEN PONOROGO
}

\author{
Tian Nur Ma'rifat ${ }^{1)}$, Arief Rahmawan ${ }^{2)}$ \\ ${ }^{1)}$ Universitas Darussalam Gontor, email : tiannurm@unida.gontor.ac.id \\ ${ }^{2)}$ Universitas Darussalam Gontor, email : arief.rahmawan@unida.gontor.ac.id
}

\begin{abstract}
ABSTRAK
Model rantai pasok halal penting untuk dikembangkan di Kabupaten Ponorogo dikarenakan besarnya kebutuhan konsumen akan adanya jaminan status halal. Terbatasnya Rumah Pemotongan Unggas bersertifikat halal yang menyebabkan keterbatasan pasokan daging ayam yang bersertifikasi halal ke konsumen. Regulasi dan konsep jaminan halal dalam sistem rantai pasok halal di Indonesia juga belum diatur secara jelas. Metode pengambilan data yang dilakukan adalah studi literatur dengan penelitian terdahulu yang terkait dengan rantai pasok halal. Standar halal yang digunakan dalam merancang manajemen rantai pasok halal adalah Dokumen Jaminan Halal HAS 23000 dari LPPOM MUI. Manajamen rantai pasok halal daging ayam dipengaruhi oleh kebijakan halal yang diatur oleh pemerintah serta dinas terkait dan juga kemampuan dari pelaku rantai pasok untuk mengaplikasikan kebijakan halal yang telah disusun.
\end{abstract}

Kata kunci : Daging Ayam, Halal, Manajemen Rantai Pasok

\section{PENDAHULUAN}

Indonesia adalah negara dengan mayoritas penduduknya beragama Islam. Salah satu kabupaten di Indonesia yang penduduk muslimnya besar adalah Ponorogo. Kabupaten Ponorogo merupakan salah satu Kabupaten di Provinsi Jawa Timur. Persentase jumlah penduduk yang beragama Islam di Kabupaten Ponorogo pada tahun 2015 adalah sebanyak 99,21\% (887.321 jiwa dari 894.332) dari keseluruhan penduduk di Kabupaten Ponorogo (BPS, 2015). Latar belakang agama dan pendidikan ini menjadikan aspek halal sebagai faktor terpenting yang dibutuhkan oleh konsumen di Kabupaten Ponorogo.

Halal merupakan syarat utama bagi konsumen muslim dalam mengkonsumsi produk pangan. Kehalalan produk pangan ditentukan dari kesesuaian proses, bahan baku hingga transportasi dari tahap hulu ke hilir produk sampai ke tangan konsumen. Lembaga Pengkajian Pangan, Obat-obatan dan Kosmetika Majelis Ulama Indonesia
(LPPOM MUI) telah menerbitkan Sistem Jaminan Halal (SJH) yang dituangkan dalam aturan HAS 23000 (Listianingsih, 2013). Dengan demikian, adanya jaminan halal menjadi kebutuhan pokok konsumen terhadap produk yang dikonsumsi yang mencakup kehalalan setiap tahap dan komponen penyusun.

Menurut data BPS (2012) dalam Deptan (2013) tingkat konsumsi masyarakat Indonesia akan daging ayam menempati urutan pertama terbesar diatas tingkat konsumsi daging sapi. Di Propinsi Jawa Timur sendiri, permintaan terhadap daging ayam tinggi khususnya daging ayam ras dibanding daging ayam bukan ras. Dalam hal tingkat produksi, dari tahun 2011-2014 Propinsi Jawa Timur menempati urutan kedua sebagai provinsi penghasil daging ayam ras dengan rata-rata persentase sebesar $11,97 \%$ dari total produksi daging ayam ras Nasional (Kementerian Pertanian RI, 2013). Di lain sisi, produsen daging ayam atau Rumah Pemotongan Unggas (RPU) masih 
sedikit yang memiliki sertifikasi halal dari MUI. Menurut data dari LPPOM MUI (2016), jumlah RPU yang telah tersertifikasi halal di Jawa Timur sebanyak 7 perusahaan. Keterbatasan jumlah RPU tersebut menyebabkan keterbatasan pasokan daging ayam yang bersertifikasi halal ke konsumen. Selain itu, regulasi terkait rantai pasok halal di Indonesia belum diatur secara jelas. Hal ini dikarenakan belum adanya konsep jaminan halal dalam sistem rantai pasok daging ayam hingga ke tangan konsumen.

Rantai pasok daging ayam di Kabupaten Ponorogo dimulai dari peternakan. Dari peternakan selanjutnya dibawa ke rumah pemotongan unggas (RPU). Daging ayam dari RPU selanjutnya dijual di pasar, ke pedagang daging ayam rumahan ataupun dijual langsung secara eceran. Kabupaten Ponorogo belum memiliki RPU yang telah tersertifikasi halal dan belum ada sistem yang mengatur pasokan daging ayam hingga ke tangan konsumen. Belum adanya manajemen rantai pasok di Kabupaten Ponorogo yang menjamin daging ayam dari produsen ke konsumen berstatus halal menjadi latar belakang dari penelitian ini.

Tujuan dari penelitian mengenai Pengembangan Model Manajemen Rantai Pasok Halal Pada Komoditas Daging Ayam di Kabupaten Ponorogo, Jawa Timur antara lain :

1) mengidentifikasi komponen dalam manajemen rantai pasok daging ayam

2) merancang model manajemen rantai pasok daging ayam yang sesuai dengan standar halal dari LPPOM MUI.

\section{METODE PENELITIAN}

Metode yang digunakan dalam makalah ini adalah observasi lapangan untuk mengetahui kondisi rantai pasok daging ayam di Kabupaten Ponorogo serta melalui kerangka konseptual yang mensintesis riset terdahulu mengenai rantai pasok halal. Kerangka konseptual dikembangkan melalui dua fase :

1) Identifikasi komponen dalam manajemen rantai pasok halal daging ayam
2) Perancangan model manajemen rantai pasok daging ayam yang sesuai dengan standar halal dari LPPOM MUI

\section{HASIL DAN PEMBAHASAN Halal}

Halal merupakan suatu definisi yang didasarkan pada kaidah hukum agama Islam. (Qardhawi, 2016) menjelaskan bahwa secara istilah, halal merupakan sesuatu yang diperkenankan, yang terlepas dari ikatan larangan, dan diizinkan oleh pembuat syari'at (hukum) untuk dilakukan. Dalam hal konsumsi makanan, halal merupakan faktor yang mengatur makanan yang boleh dikonsumsi oleh masyarakat yang beragama Islam.

\section{Supply Chain}

Menurut (Harrison, van Hoek, \& Skipworth, 2014) Supply chain atau yang biasa disebut rantai pasok adalah suatu jaringan antar pihak yang secara bersamasama mengubah komoditas dasar (upstream) menjadi finished good product (downstream) yang menambah nilai bagi pelanggan/konsumen. Pihak yang terlibat dalam rangkaian supply chain bertanggung jawab secara langsung dalam melakukan proses untuk menambahkan nilai tambah dari suatu produk tersebut. Sebagai contoh produk kertas telah melalui proses rangkaian rantai pasok yang melibatkan pihak pembibit biji kayu, dibudidayakan oleh forester, ditebang oleh penebang kayu, diproses menjadi bubur kayu $\rightarrow$ kertas mentah $\rightarrow$ gelondongan kertas $\rightarrow$ lembaran kertas. Setiap pihak turut berkontribusi pada proses transformasi raw material menjadi bahan jadi. Gambar 1. menunjukkan aktivitas rantai pasok dengan menghubungkan aktivitas upstream dan aktivitas downstream.

Aktivitas upstream adalah suatu aktivtias buy side yang dilakukan suatu organisasi manufaktur dalam mendapatkan bahan material untuk diproses di manufaktur tersebut. Sedangkan aktivitas downstream 
adalah suatu aktivitas yang dilakukan perusahaan untuk mendistribusikan produk jadi mereka (sell side). Dalam aktivitas upstream, setiap supplier memiliki tingkatan atau yang diklasifikasikan sebagai tier. Seperti yang terlihat pada gambar 2, bahwa setiap tingkatan memiliki tipe bahan material yang berbeda-beda.

\section{Manajemen Rantai Pasok}

Definisi dari manajemen rantai pasok (supply chain management atau disingkat SCM) semakin berkembang diikuti dengan semakin kompleksnya proses transformasi barang mulai dari bahan baku menjadi produk akhir. SCM menjadi keilmuan yang banyak diteliti untuk pengelolaan proses perjalanan barang secara optimal. Secara umum makna dari SCM adalah suatu pengelolaan aliran barang dan jasa mulai dari hulu ke hilir yang mencakup penyimpanan material, inventori, proses transformasi material, yang setiap proses menghasilkan nilai tambah dari produk tersebut. Cakupan dari SCM meliputi fungsional dan organizational (Chopra \& Meindl, 2016). Dari aspek fungsional, fungsi dari suatu organisasi seperti produksi, purchasing, assembling, research and development dan sebagainya, terlibat dalam proses supply chain tersebut. Sedangkan aspek dari organizational adalah terdapat keterkaitan antara pihak upstream dan pihak downstream di dalam aktivtias supply chain. Manajemen rantai pasok dapat diilustrasikan pada gambar 3. mengenai aliran rantai pasok, aktivitas dan pihak yang terlibat sebagai satu kesatuan yang terintegrasi secara continue. Aspek fungsional organisasi/perusahaan seperti marketing, sales, research and development dan forecasting menjembatani antara penyuplai dengan konsumen.

\section{Manajemen Rantai Pasok Halal}

Rantai pasok halal adalah rangkaian proses mulai dari sumber pasokan sampai mencapai ke konsumen harus terjamin kehalalannya. Seperti dalam penelitian Omar et. al (2011), rantai pasok halal daging ayam akan dimulai dari peternakan dan rumah pemotongan hewan, dan selanjutnya daging ayam diangkut dan disimpan sebelum sampai ke pelanggan. Hal ini untuk memastikan bahwa halal tidak hanya diterapkan untuk produk atau makanan tetapi juga untuk semua aktivitas dalam rantai pasok yang meliputi penanganan dan pengelolaan produk (manajemen persediaan dan penanganan bahan). Menurut Zulfakar et.al (2014) semua komponen dalam rantai pasok, dari hulu ke hilir, harus memiliki tanggung jawab individu dan terintegrasi untuk melindungi produk makanan halal agar tidak terkontaminasi silang, baik sengaja maupun tidak sengaja.

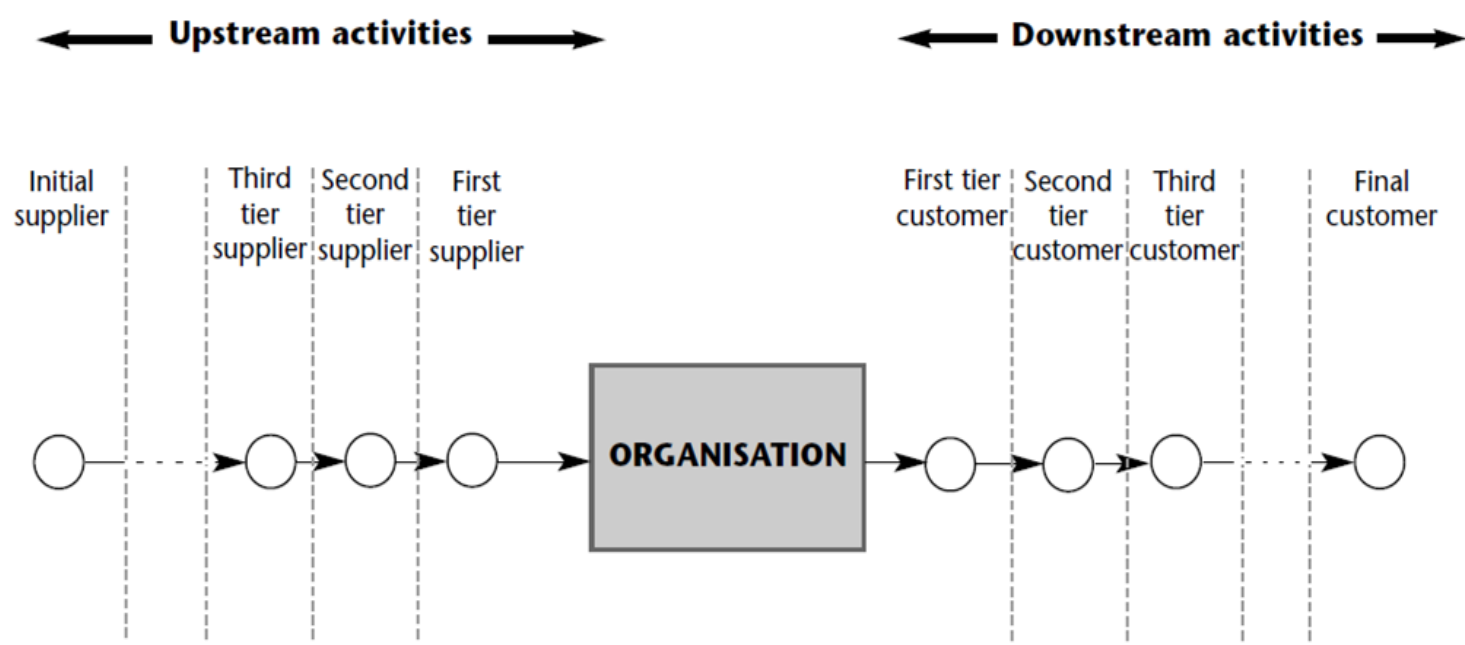

Gambar 1. Aktivitas supply chain (Sumber: Waters, 2003) 


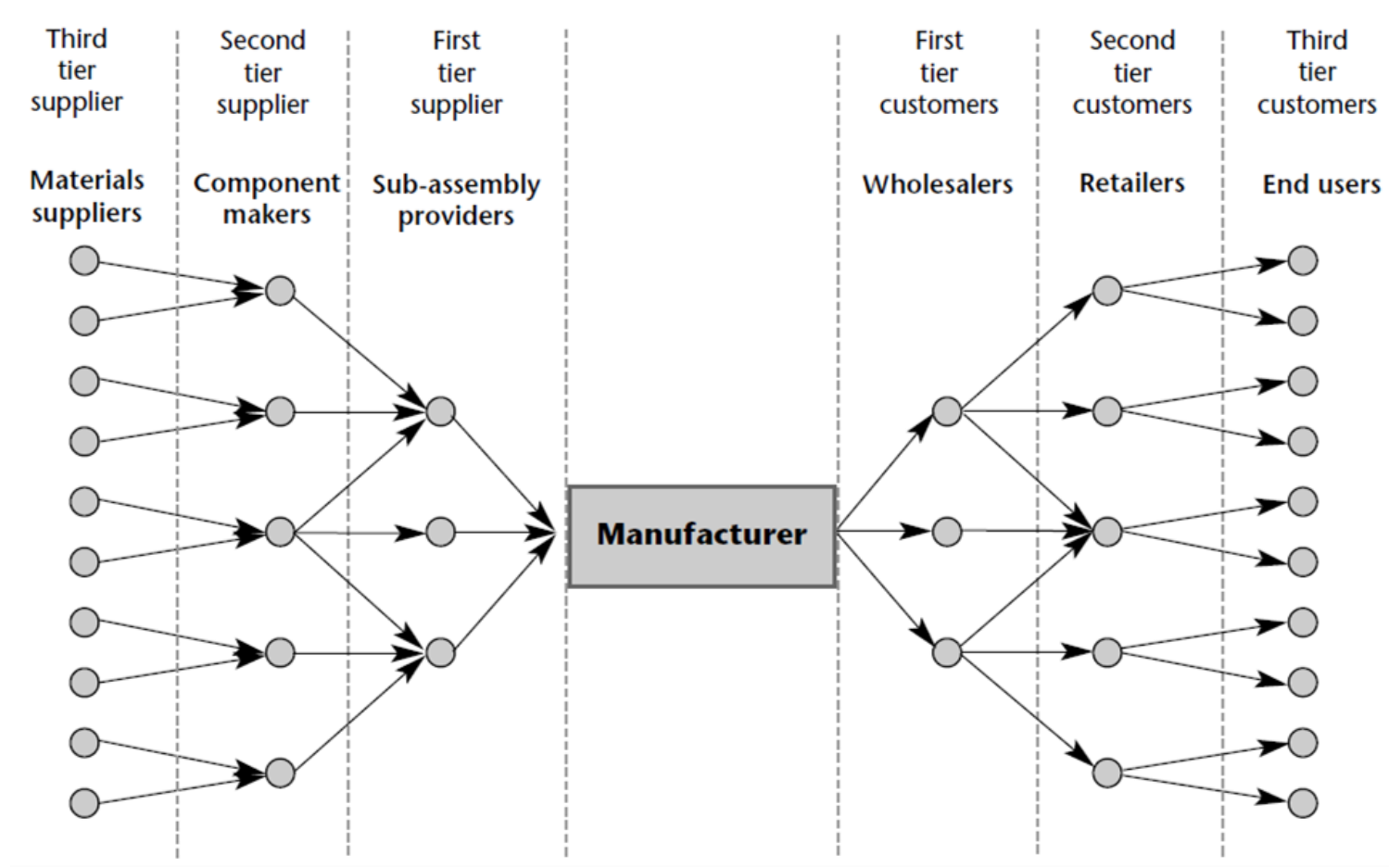

Gambar 2. Tingkatan (tier) penyuplai dan konsumen pada suatu manufaktur ( Sumber : Waters, 2003)

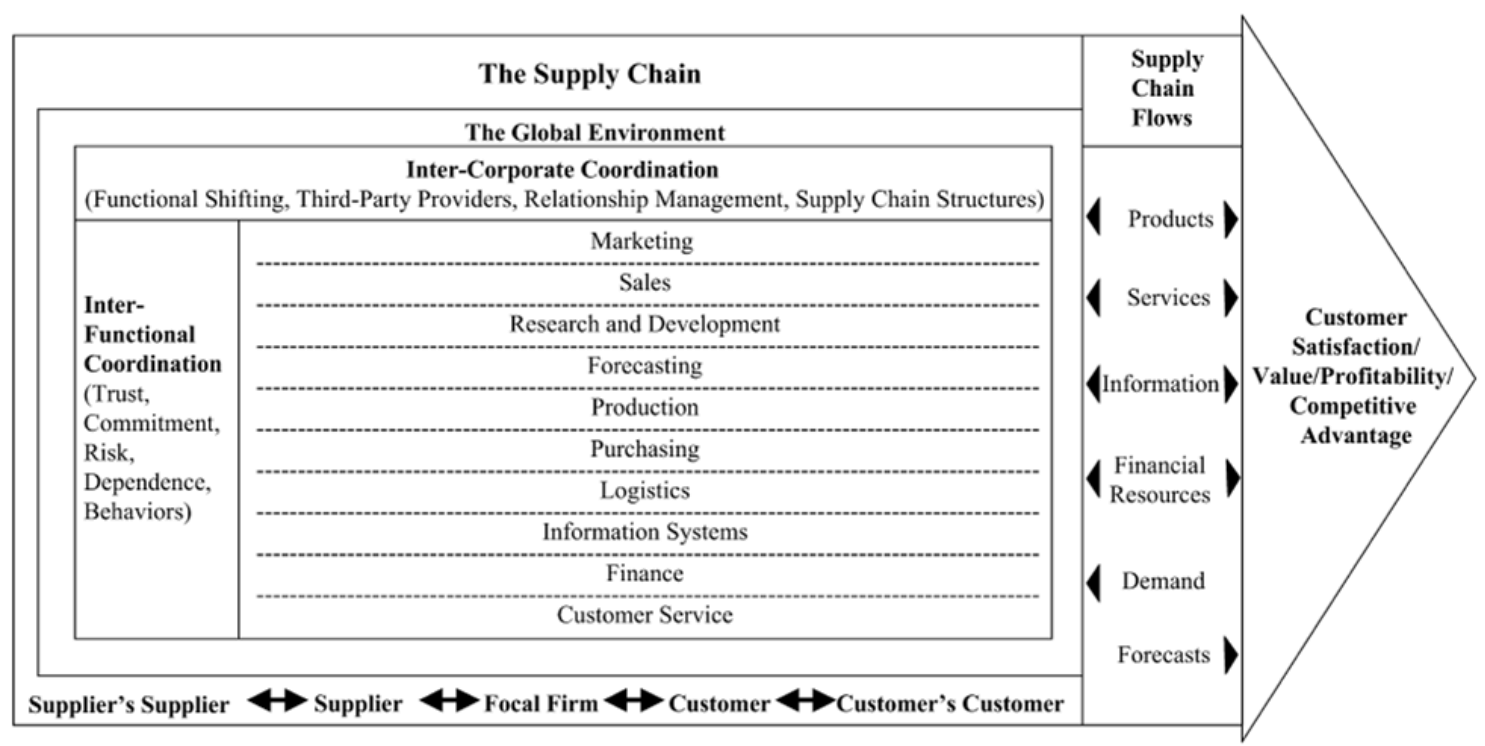

Gambar 3. Model Manajemen Rantai Pasok (Sumber : Christopher, 2016)

Lebih lanjut, dibutuhkan strategi dalam membangun manajemen rantai pasok halal. Marketing Intelligent dan rantai pasok berorientasi strategis serta terstruktur melalui sistem Jaminan Halal harus diadopsi. Produser produk Muslim, pertama harus memahami dan mempelajari rantai pasokan dan proses produksi. Rantai pasok strategis adalah proses berulang yang mengevaluasi trade-off manfaat biaya dari komponen operasional (Muhammad, 2009).

Berikut adalah strategi pada aspek organizational dalam manajemen rantai pasok halal.

1. Struktur Rantai Pasok yang Berorientasi pada Sistem Jaminan 
Halal pada tingkat Operasional dan Strategis

Integrasi antar departemen dalam perusahaan dan diluar perusahaan menjadi elemen penting untuk menciptakan struktur rantai pasok yang sesuai dengan rantai pasok stratgeis. Manajemen halal adalah mengelola semua fungsi dan kegiatan yang diperlukan untuk menentukan dan mencapai produk halal. Manajemen halal diterapkan di semua sektor yang mencakup struktur organisasi, tanggung jawab, prosedur, aktivitas, kemampuan, dan sumber daya yang bersama-sama bertujuan untuk memastikan bahwa produk, proses, atau layanan akan memenuhi tujuan yang dinyatakan atau tersirat, yaitu produksi produk halal. Menurut Wiengarten et.al (2010), integrasi antar pelaku dalam rantai pasok dapat dicapai melalui Colaborative Supply Chain yang mampu menghubungkan antara bagian internal perusahaan dan pihak eksternal. Colaborative Supply Chain dapat dicapai melalui penggunaan database informasi bisnis bersama dan proses pengambilan keputusan bersama.

2. Penggunaan sistem pemasaran dengan inteligent marketing di semua struktur rantai pasok berbasis Resource Base View (RBV). RBV menekankan hubungan antara keunggulan kompetitif dan organisasi internal perusahaan. RBV menggambarkan interaksi antara sumber daya internal perusahaan dengan lingkungan eksternal di mana strategi perusahaan yang sukses merupakan konsekuensi dari faktor eksternal dan internal karena perubahan lingkungan dapat mengubah nilai sumber daya.

Pada level implementasi teknis manajemen rantai pasok halal adalah adanya pelatihan mengenai rantai pasok halal. Menurut Ernest dan Lau (2012) salah satu masalah yang dalam implementasi sistem halal adalah kurangnya kesadaran halal di antara para pelaku rantai pasok tentang konsep halal dan pemahaman tentang bahan baku, pengolahan dan penyimpanan. Menurut Hashim dan Shariff (2015) tingginya tuntutan dan kebutuhan industri halal yang semakin meningkat mendorong perusahaan untuk melaksanakan pelatihan rantai pasok halal.

\section{Model Manajemen Rantai Pasok Halal}

Dalam perkembangan rantai pasok halal saat ini, dibutuhkan adanya sistem yang menjamin bahwa rantai pasok halal dapat berjalan secara berkelanjutan sehingga industri halal dapat berkembang pada tingkat global. Industri produk pangan halal khususnya, Ali dan Sulaiman (2018) menyatakan dalam penelitiannya bahwa dibutuhkan adanya konsep rantai pasok halal yang beberapa kriteria sehingga tercipta adanya integritas dalam rantai pasok halal produk pangan antara lain :

- Bahan baku yang tidak tercampur dengan bahan tambahan

- Kualitas dan Kuantitas Suplier

- Kejelasan asal dari bahan

- Kualitas produk

- Sumber Daya Manusia

Dari hasil telaah literatur dan studi kasus di Kabupaten Ponorogo, diperoleh komponen-komponen yang terlibat dalam rantai pasok daging ayam serta komponen pendukung terselenggaranya manajemen rantai pasok halal yang berkelanjutan. Dari beberapa aspek tersebut diintegrasikan ke dalam suatu model manajemen rantai pasok daging ayam yang terdiri dari pelaku rantai pasok, aspek fungsional dan organisational dalam rantai pasok serta strategi manajemen rantai pasok halal. Berikut adalah model grafis mengenai manajemen rantai pasok daging ayam. 


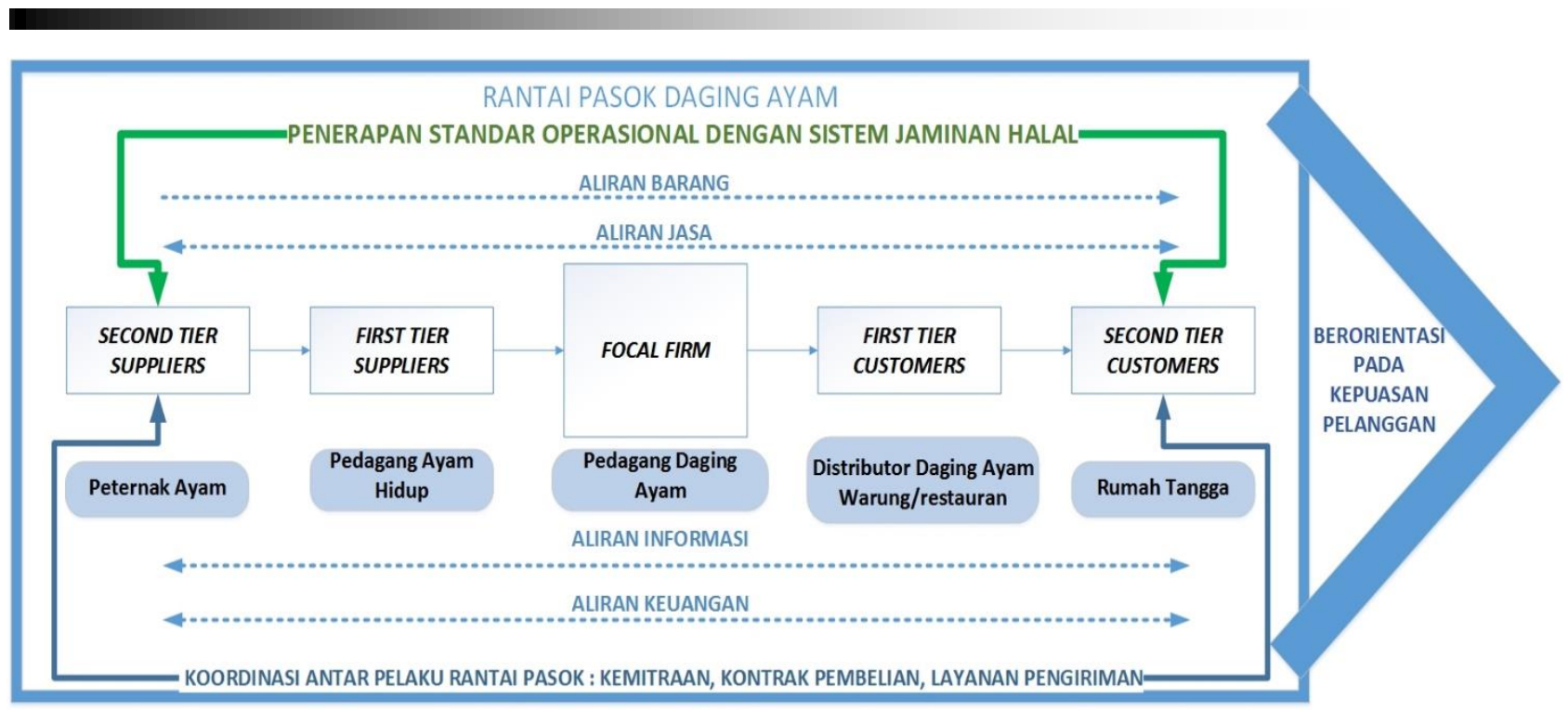

Gambar 4. Model Manajemen Rantai Pasok Halal Daging Ayam

Dalam implementasi model tersebut, dibutuhkan peran dan tanggung jawab dari Pemerintah Daerah selaku pembuat kebijakan secara umum dan dinas terkait selaku pihak yang menjalankan kebijakan, membuat aturan teknis lapangan dan eksekutor di lapangan. Hal ini dikarenakan pada studi kasus di Kabupaten Ponorogo, pelaku rantai pasok memiliki keterbatasan dalam pelaksanaan manajemen rantai pasok halal diantaranya karena rendahnya motivasi dan kesadaran dalam penerapan rantai pasok halal serta rendahnya informasi terkait hal tersebut. Berdasarkan penelitian dari Ma'rifat (2017), pelaku rantai pasok belum memiliki kesadaran dalam menjalankan prosedur ketelusuran halal sebagai bagian dari implementasi rantai pasok halal. Oleh karena itu, dinas terkait seperti Dinas Pertanian dan Peternakan memiliki tanggung jawab dalam pengendalian aspek operasional berupa implementasi standar Sistem Jaminan Halal dan Good Handling Practises pada tingkat pelaku rantai pasok. Dinas Perindustrian dan Perdagangan memiliki wewenang dalam pembuatan sistem kerjasama dalam hal kontrak pembelian, distribusi dan pemasaran antar pelaku rantai pasok sehingga kegiatan dalam rantai pasok dapat berjalan efisien.

\section{KESIMPULAN}

1) Komponen dalam manajemen rantai pasok halal daging ayam diantaranya adalah pelaku rantai pasok daging ayam, adanya aspek operasional berdasarkan Standar HAS 23000, serta aspek fungsional dalam rantai pasok.

2) Model manajemen rantai pasok daging ayam yang sesuai dengan standar halal dari LPPOM MUI mencakup seluruh komponen dalam manajemen rantai pasok halal daging ayam, interaksi antar pelaku rantai pasok dan strategi yang menjamin model berkelanjutan.

\section{Daftar Pustaka}

Ali, M.H. and Suleiman, N., 2017. Eleven shades of food integrity: A halal supply chain perspective. Trends in Food Science \& Technology.

Chopra, S., \& Meindl, P. 2016. Supply chain management: Strategy, planning and operation (6th ed.). New York: Pearson Education, Inc.

Christopher, M. 2011. Logistics \& supply chain management (4th ed.). Harlow: Pearson Education Limited.

Ernest, C. D.\& Lau, W. M. 2012. Will those targeted pay more? The Issue of Halal Logo. Osman MohdZain (ed). Reading in Marketing: An Islamic Perspective 
Hashim, H.I.C. and Shariff, S.M.M., 2016. Halal supply chain management training: Issues and challenges. Procedia Economics and Finance, 37, pp.33-38.

Harrison, A., van Hoek, R., \& Skipworth, H. 2014. Logistics management and strategy: Competing through the supply chain (5th ed.). Harlow: Pearson Education Limited.

Majelis Ulama Indonesia. Persyaratan Sertifikasi Halal MUI. http://www.halalmui.org/muil4/index.php/m ain/go_to_section/58/1366/page/1

Ma'rifat, T.N., 2017. Perception on Halal Traceability on Chicken Meat Supply Chain. Agroindustrial Technology Journal, 1(1), pp.33-42.

Kementerian Pertanian RI. 2013. Konsumsi daging menurut jenis daging dan daging olahan per kapita, 2007-2011. Retrieved from Kementerian Pertanian RI Website: http://www.pertanian.go.id/pdfeisNAK2013/KonsumsiJenisDaging\&olahan.pdf

Listianingsih, W. 2013. Mudahkah sertifikasi halal? Retrieved 2016, from AGRINA -
Inspirasi

Agribisnis

Indonesia:

http://www.agrina-

online.com/redesign2.php?rid=7\&aid=4412

Omar, E. N., \& Jaafar, H. S. 2011. Halal supply chain in the food industry - a conceptual model. IEEE Symposium on Business, Engineering and Industrial Applications (ISBEIA), 384-389.

Qardhawi, Y. 2016. Halal dan haram dalam Islam. (T. E. Intermedia, Ed.) Solo: PT Era Adicitra Intermedia.

Waters, D. 2003. Logistics: An introduction to supply chain management. New York: Palgrave Macmillan.

Wiengarten, F., Humphreys, P., Cao, G., Fynes, B. and McKittrick, A., 2010. Collaborative supply chain practices and performance: exploring the key role of information quality. Supply Chain Management: An International Journal, 15(6), pp.463-473.

Zulfakar, M. H., Anuar, M. M., \& Ab Talib, M. S. 2014. Conceptual framework on halal food supply chain integrity enhancement. Procedia - Social and Behavioral Sciences, 121, 58-67. 